\title{
The preoperative lymphocyte to monocyte ratio predicts clinical outcome in patients with stage III colon cancer
}

\author{
M Stotz ${ }^{1,2}$, M Pichler $^{1}$, G Absenger ${ }^{1}$, J Szkandera ${ }^{1,2}$, F Arminger $^{1}$, R Schaberl-Moser ${ }^{1}$, H Samonigg $^{1}$, \\ T Stojakovic ${ }^{3}$ and A Gerger ${ }^{\star}, 1,2$ \\ ${ }^{1}$ Division of Clinical Oncology, Department of Medicine, Medical University of Graz, Auenbruggerplatz 15, 8036 Graz, Austria; \\ ${ }^{2}$ Research Unit Genetic Epidemiology and Pharmacogenetics, Division of Clinical Oncology, Medical University of Graz, \\ Auenbruggerplatz 15, 8036 Graz, Austria and ${ }^{3}$ Clinical Institute of Medical and Chemical Laboratory Diagnostics, Medical \\ University of Graz, Auenbruggerplatz 15, 8036 Graz, Austria
}

Background: Inflammation has a critical role in the pathogenesis and progression of cancer. The lymphocyte to monocyte ratio (LMR) could be shown to be prognostic in haematologic neoplasia. In this study, we analysed the LMR with clinical outcome in stage II and III colon cancer patients.

Methods: Three hundred and seventy-two patients with stage II and III colon cancer were included in this retrospective study. Kaplan-Meier curves and multivariate Cox-regression analyses were calculated for time to recurrence (TTR) and overall survival (OS).

Results: Including all patients, the elevated preoperative LMR was significantly associated with increased TTR and OS in multivariate analysis (HR: $0.47,95 \% \mathrm{Cl}: 0.29-0.76, P=0.002 ; \mathrm{HR}: 0.51,95 \% \mathrm{Cl}: 0.31-0.83, P=0.007$; respectively). In subanalyses, the association was limited to patients with stage III (HR: $0.40,95 \% \mathrm{Cl}: 0.22-0.72, P=0.002)$, in contrast to patients with stage II (HR: $0.40,95 \% \mathrm{Cl}$ : $0.28-1.66, P=0.397)$. When the subgroup of patients with 'high-risk' $L M R \leqslant 2.83$ was analysed, no benefit of adjuvant 5-FU-based chemotherapy could be found (HR: 0.99; 95\% $\mathrm{Cl}$ : 0.60-1.63; $P=0.953$ ).

Conclusion: The LMR might be an independent prognostic marker for TTR in stage III colon cancer patients. Our results further suggest that high-risk patients based on the LMR do not benefit from adjuvant chemotherapy. Independent validation of our findings is warranted.

In Europe, similar to the United States, colorectal cancer ranks third place of cancer overall and even second leading cause of cancer-related death affecting both, males and females (Siegel et al, 2013). There is still a high mortality caused by colorectal cancer, mainly resulting from tumour dissemination. Despite multiple systemic treatment options in advanced colon cancer, surgery is still the mainstay of treatment in non-metastatic disease. In nonmetastatic disease 5-year survival rates range from about 40 to 90 percent, depending on clinical stage (O'Connell et al, 2004). 5 -fluorouracil-based chemotherapy is the standard treatment for patients with stage III and high-risk stage II colon cancer after curative surgery (Schmoll et al, 2012). However, a large number of colon cancer patients does not benefit from adjuvant treatment, either because these patients are cured by surgery alone or because they develop tumour recurrence or distant metastases despite adjuvant treatment. There is intense interest in the elucidation of prognostic and predictive biomarkers that will improve clinical outcome through patient classification. Despite the fact, that up to now, promising results for molecular biomarkers could be found, they still have not come to routine clinical practice, due to high 
costs or missing standardisation and evidence (Roth et al, 2010; Salazar et al, 2011).

The knowledge about the bilateral influence of cancer and inflammation was discovered over a century ago; however, interest in this topic has revived in the last few years. Nevertheless, up to now, tumour-inflammation interaction has not been completely explained. The variation in systemic inflammatory cell amount might be a valuable pretreatment prognostic marker for stratifying patients at risk for tumour recurrence in colon cancer, as it could be shown for example in the neutrophil to lymphocyte ratio or platelet to lymphocyte ratio in various cancer entities (Gomez et al, 2008; Cho et al, 2009; Idowu et al, 2012; Kwon et al, 2012; Raungkaewmanee et al, 2012).

One reason for these findings could be the accumulation of genetic failures over time, leading to oncogenic activation, simultaneously, inactivation of tumour suppressor genes, which are responsible for higher transcription of inflammatory mediators resulting in an inflammatory condition in tumour cell environment. Another reason might be, that tumour-related leukocytes, especially monocytes, which are main regulators of cancer inflammation, have an essential role in systemic inflammatory response to tumorous disease (Allavena et al, 2008; Mantovani et $a l, 2008)$. Up to now there are no data in solid tumours regarding the lymphocyte to monocyte ratio as a prognostic marker. However, recent results in haematologic malignancies suggest that survival benefit is associated with an increased LMR (Li et al, 2012; Porrata et al, 2012a). The LMR might be a good reflection of both, lymphopenia that is a surrogate marker of weak immune response and an increased monocyte count, standing for a microenvironment surrogate marker of high tumour burden.

On the basis of the recent findings and the biological plausibility, the aim of the present study was to investigate the clinical effect of the preoperative LMR for time to recurrence (TTR) and overall survival (OS) in a large cohort of patients with stage II and III colon cancer to provide an easily available biomarker.

\section{MATERIALS AND METHODS}

Subjects. A total of 372 patients with histologically confirmed stage II and III colon cancer were included in this retrospective study. All patients were treated and/or included in the colon cancer surveillance programme between 1996 and 2011 at the Division of Clinical Oncology, Department of Medicine, Medical University of Graz, Austria. Follow-up care was performed in regular intervals (3 month intervals in years 1-3, 6 month intervals in years 4-5 and 12 month intervals in years 6-10 after diagnosis). Follow-up investigations included clinical check-up, laboratory including CEA and CA 19-9, radiological assessment (liver scan and chest $\mathrm{X}$-ray every 6 months within the first 3 years) and colonoscopy every 2 years. Clinical and histopathological features were retrospectively obtained from the patients' history. Follow-up data of all patients were available. The preoperative white blood cell count was obtained within 3 days before surgery and performed for routine clinical practice. The LMR was calculated from this routinely performed preoperative blood cell count as the absolute count of lymphocytes divided by the absolute count of monocytes. Analysis of the white blood cell count was performed in the general routine laboratory of our hospital. This study has been approved by the Institutional Review Board (IRB) of the Medical University of Graz (25-137 ex 12/13).

Statistical analysis. The primary end point of the study was TTR; the secondary end point was OS. TTR was calculated from the date of diagnosis of colon cancer to the date of tumour recurrence and was censored at time of death or at the last follow up if the patients remained tumour free at that time. Overall survival was calculated from the time of diagnoses to the date of death of any cause. The optimal cutoff levels for the LMR were determined by applying receiver operating curve (ROC) analysis (Mroczko et al, 2007). The LMR was correlated with the clinicopathological features by $\chi^{2}$-test. The association between the clinicopathological features and the LMR with TTR and OS was analysed using Kaplan-Meier curves and compared by the log-rank test. In the multivariate Cox-regression analysis, the model was adjusted for prognostic clinicopathological factors significantly associated with TTR and OS in univariate analysis. Hazard ratios (HRs) estimated from the Cox-regression analysis were reported as relative risks with corresponding 95\% confidence intervals (Roth et al, 2010). All statistical analyses were performed using the Statistical Package for Social Sciences version 20.0 (SPSS Inc., Chicago, IL, USA). A two-sided $P<0.05$ was considered statistically significant.

\section{RESULTS}

Baseline patient characteristics and tumour biological factors are shown in Table 1. The median age at time of diagnosis was 64 years (range 27 to 95 years). The median follow-up time was 68 months (range 1 to 190 months). Applying ROC analysis, the optimal cutoff levels for the LMR was 2.83 for TTR and 2.14 for OS, respectively. The ROC curves are shown in Figure 1A and B. The area under the curve was 0.60 for TTR and 0.62 for OS.

In our study cohort, we found significant associations between tumour invasion depth, lymph node involvement and clinical stage with TTR and OS (Table 1). Since clinical stage derives from tumour invasion depth and lymph node involvements, only clinical stage was included in further multivariate models. None of the clinicopathological features were associated with the LMR (Table 2).

Of the 372 colon cancer patients, 94 (25.3\%) developed tumour recurrence and 72 (19.4\%) died within the follow-up period. In 23 patients, the lymphocyte and/or monocyte count and therefore the LMR were missing. The tumour recurred in 69 (32.1\%) out of 215 patients with a $L M R \leqslant 2.83$ and in $21(15.7 \%)$ out of 134 patients with a $\operatorname{LMR}>2.83(P=0.001)$. Death occurred in $39(29.3 \%)$ out of 133 patients with a LMR $\leqslant 2.14$ and in $28(13 \%)$ out of 216 patients with a $\operatorname{LMR}>2.14(P<0.001)$, respectively. In four patients with tumour recurrence and five patients who died within the follow-up period the LMR was missing.

In univariate analysis, the elevated preoperative LMR was significantly associated with increased TTR (HR: 0.47, 95\%CI: $0.29-0.76, P=0.002$; Figure $2 \mathrm{~A}$ ) and remained significant in the multivariate analysis including clinical stage (HR: $0.47,95 \% \mathrm{CI}$ : $0.29-0.76, P=0.002$; clinical stage: HR: 2.38 , 95\%CI: $1.47-3.85$, $P<0.001)$. Patients with a LMR $>2.83$ showed a median TTR of 127 months. In contrast, patients with a LMR $\leqslant 2.83$ had a median TTR of 114 months. In OS analysis, the elevated preoperative LMR was significantly associated with increased OS in univariate analysis (HR: 0.48, 95\%CI: $0.29-0.78, P=0.003$; Figure $2 \mathrm{~B}$ ) and multivariate analysis including clinical stage (HR: $0.51,95 \% \mathrm{CI}$ : $0.31-0.83, P=0.007$; clinical stage: HR: 2.03 , 95\%CI: $1.16-3.53$, $P=0.013)$. Patients with a LMR $>2.14$ showed a median OS of 139 months, whereas patients with a LMR $\leqslant 2.14$ had a median OS of 124 months.

In interaction analysis for TTR, there was a significant association between LMR and clinical stage $(P=0.005)$. Including only patients with stage II we found no significant association between LMR $>2.83$ and TTR (HR 0.40, 95\%CI 0.28-1.66, $P=0.397$; Figure 2C). In patients with stage III, the association was significant (HR: $0.40,95 \% \mathrm{CI}$ : $0.22-0.72, P=0.002$; Figure $2 \mathrm{D}$ ). 
Table 1. Baseline patient characteristics and their association with TTR and OS in univariate analysis

\begin{tabular}{|c|c|c|c|c|c|c|}
\hline \multirow[b]{2}{*}{ Parameter } & \multirow[b]{2}{*}{$n$} & \multirow[b]{2}{*}{$\%$} & \multicolumn{2}{|c|}{ TTR } & \multicolumn{2}{|l|}{ OS } \\
\hline & & & HR $(95 \% \mathrm{Cl})$ & $\boldsymbol{P}$-value & HR $(95 \% \mathrm{Cl})$ & $P$-value \\
\hline \multicolumn{7}{|l|}{ Gender } \\
\hline $\begin{array}{l}\text { Male } \\
\text { Female }\end{array}$ & $\begin{array}{l}217 \\
155\end{array}$ & $\begin{array}{l}58.3 \\
41.7\end{array}$ & $\begin{array}{c}1 \text { (reference) } \\
1.19(0.80-1.79)\end{array}$ & 0.417 & $\begin{array}{c}1 \text { (reference) } \\
1.06(0.66-1.70)\end{array}$ & 0.801 \\
\hline \multicolumn{7}{|c|}{ Tumour location } \\
\hline $\begin{array}{l}\text { Left } \\
\text { Right }\end{array}$ & $\begin{array}{l}130 \\
242\end{array}$ & $\begin{array}{l}34.9 \\
65.1\end{array}$ & $\begin{array}{c}1 \text { (reference) } \\
1.06(0.69-1.63)\end{array}$ & 0.781 & $\begin{array}{r}1 \text { (reference) } \\
0.77(0.48-1.23)\end{array}$ & 0.273 \\
\hline \multicolumn{7}{|c|}{ Tumour invasion depth } \\
\hline $\begin{array}{l}\text { T1 } \\
\text { T2 } \\
\text { T3 } \\
\text { T4 }\end{array}$ & $\begin{array}{c}7 \\
\\
18 \\
260 \\
87\end{array}$ & $\begin{array}{r}1.9 \\
\\
4.8 \\
69.9 \\
23.4\end{array}$ & $\begin{array}{c}1 \text { (reference) } \\
0.65(0.06-7.17) \\
1.43(0.20-10.34) \\
2.78(0.38-20.36)\end{array}$ & 0.010 & $\begin{array}{l}\text { NA, because of the low number of events for T1 } \\
\text { and T2 (T1-3 versus T4: } 2.487(1.53-4.04))\end{array}$ & $<0.001$ \\
\hline \multicolumn{7}{|c|}{ Lymph node involvement } \\
\hline $\begin{array}{l}\text { N0 } \\
\text { N1 } \\
\text { N2 } \\
\text { Unknown }\end{array}$ & $\begin{array}{c}156 \\
142 \\
73 \\
1\end{array}$ & $\begin{array}{r}41.9 \\
38.2 \\
19.6 \\
0.3\end{array}$ & $\begin{array}{c}1 \text { (reference) } \\
1.47(0.87-2.48) \\
4.02(2.42-6.69)\end{array}$ & $<0.001$ & $\begin{array}{c}1 \text { (reference) } \\
1.25(0.69-2.26) \\
3.28(1.85-5.83)\end{array}$ & $<0.001$ \\
\hline \multicolumn{7}{|c|}{ Tumour grade } \\
\hline $\begin{array}{l}\text { G1 } \\
\text { G2 } \\
\text { G3 } \\
\text { Unknown }\end{array}$ & $\begin{array}{c}23 \\
240 \\
107 \\
2\end{array}$ & $\begin{array}{r}6.2 \\
64.5 \\
28.8 \\
0.5\end{array}$ & $\begin{array}{r}1 \text { (reference) } \\
1.39(0.51-3.83) \\
1.46(0.51-4.16)\end{array}$ & 0.776 & $\begin{array}{c}1 \text { (reference) } \\
0.78(0.28-2.20) \\
1.34(0.47-3.83)\end{array}$ & 0.092 \\
\hline \multicolumn{7}{|c|}{ Tumour stage } \\
\hline $\begin{array}{l}\text { II } \\
\text { III } \\
\text { Unknown }\end{array}$ & $\begin{array}{c}154 \\
217 \\
1\end{array}$ & $\begin{array}{r}41.4 \\
58.3 \\
0.3\end{array}$ & $\begin{array}{r}1 \text { (reference) } \\
2.36(1.48-3.75)\end{array}$ & $<0.001$ & $\begin{array}{r}1 \text { (reference) } \\
1.86(1.12-3.11)\end{array}$ & 0.017 \\
\hline \multicolumn{7}{|c|}{ Adjuvant chemotherapy } \\
\hline $\begin{array}{l}\text { No } \\
\text { Yes } \\
\text { Unknown }\end{array}$ & $\begin{array}{c}141 \\
230 \\
1\end{array}$ & $\begin{array}{r}37.9 \\
61.8 \\
0.3\end{array}$ & $\begin{array}{r}1 \text { (reference) } \\
1.12(0.73-1.72)\end{array}$ & 0.605 & $\begin{array}{c}1 \text { (reference) } \\
0.73(0.73-1.72)\end{array}$ & 0.181 \\
\hline
\end{tabular}

To evaluate if 'high-risk' patients based on LMR $\leqslant 2.83$ benefit from adjuvant chemotherapy compared with surgery alone, we performed a Kaplan-Meier analysis and log-rank test for this subgroup. According to the treatment regimen (surgery alone versus adjuvant chemotherapy), no significant difference in TTR was identified in this high-risk subgroup (HR: 0.99; 95\%CI: $0.60-1.63 ; P=0.953$; Figure $2 \mathrm{E}$ ).

\section{DISCUSSION}

In the present study, we examined a large cohort of patients with stage II and III colon cancer and found a significant association between the lymphocyte to monocyte ratio and TTR and OS. In subanalyses for TTR, the association was limited to patients with stage III colon cancer. Furthermore, our results suggest that 'highrisk' patients based on $\mathrm{LMR} \leqslant 2.83$ do not benefit from adjuvant 5-FU-based chemotherapy. To the best of our knowledge this is the first study investigating the LMR in colon cancer, whereas the neutrophil to lymphocyte ratio and the derived neutrophil to lymphocyte ratio (absolute count of neutrophils divided by the absolute white cell count minus the absolute count of neutrophils; dNLR) and the platelet to lymphocyte ratio and their prediction on clinical outcome in different tumour entities have already been shown in various studies (Gomez et al, 2008; Cho et al, 2009; Kaneko et al, 2012; Raungkaewmanee et al, 2012; Absenger et al, 2013).

Growing evidence suggests an important role of inflammation in cancer progression and metastasis. Dunn et al (2004) showed that lymphocytes are basic components of the adaptive and innate immune system and the cellular basis of immunosurveillance and immunoediting. Rabinowich et al (1987) found lymphocytes, infiltrating to tumour microenvironment as a trigger for an immunological antitumor reaction. Moreover CD8 + and CD4 + T-lymphocyte interaction among each other could be proven to be essential in anti-tumour reaction of the immune system, by inducing tumour cell apoptosis (Rosenberg, 2001; Zikos et al, 2011). 
A

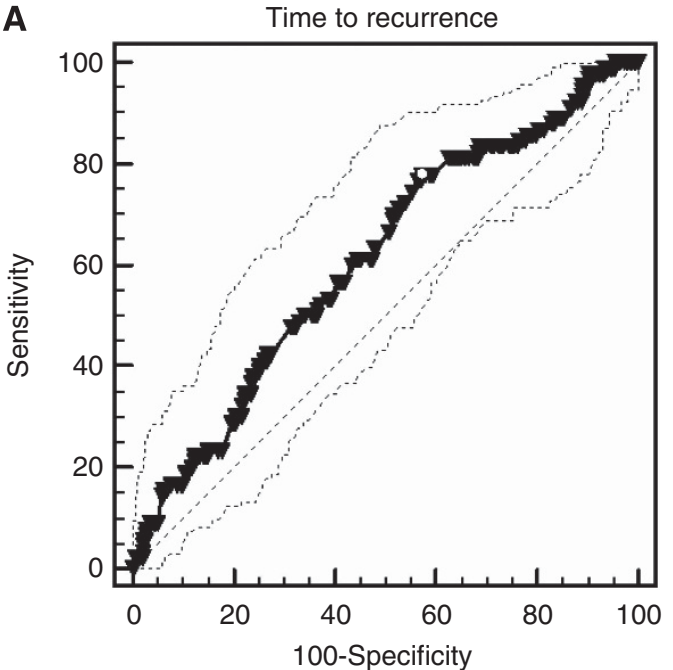

B

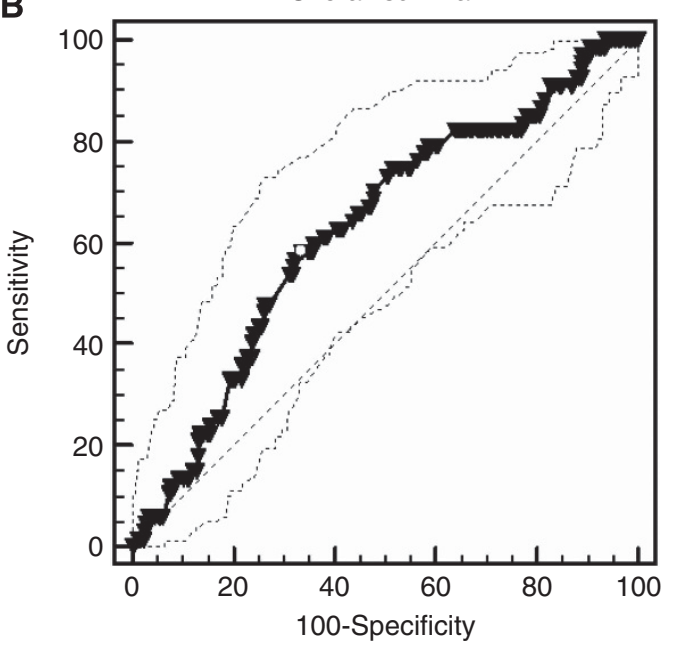

Figure 1. (A) Receiver-operator characteristic curve for TTR. (B) Receiver-operator characteristic curve for OS.

In general, a low lymphocyte amount might be responsible for a weak, insufficient immunologic reaction to the tumour (Hoffmann et al, 2002). Tumour-infiltrating leukocytes including neutrophils and monocytes, however, have a crucial role in tumour development and progression (Mantovani et al, 2008). Macrophages, which are more differentiated monocytes, develop from cells of the mononuclear phagocytic lineage that show specific phenotypic characteristics. The role of macrophages/monocytes in cancer development and progression is controversial, as inhibiting as well as enhancing potential of monocytes in human cancer have been shown (Mytar et al, 2008). Previous data showed a protective effect of Kupffer cells (macrophages of the liver) by eliminating circulating tumour cells (Heuff et al, 1993). This is line with a study by Fidler and Schroit (1988) demonstrating that macrophages are able to kill tumour cells. However, there is an increasing evidence that the tumour-associated macrophages (TAMs) enhance tumour progression. Poor clinical outcome associated with macrophage density could be shown by Bingle et al (2002). Pollard and colleagues proved that macrophages support tumour-associated angiogenesis as well as tumour cell invasion, migration and intravasation and even lead to a suppression of anti-tumour immune reaction (Pollard, 2004; Condeelis and Pollard, 2006). Colony-stimulating factor 1 (CSF-1), a major lineage regulator for macrophages (Pollard, 2009),

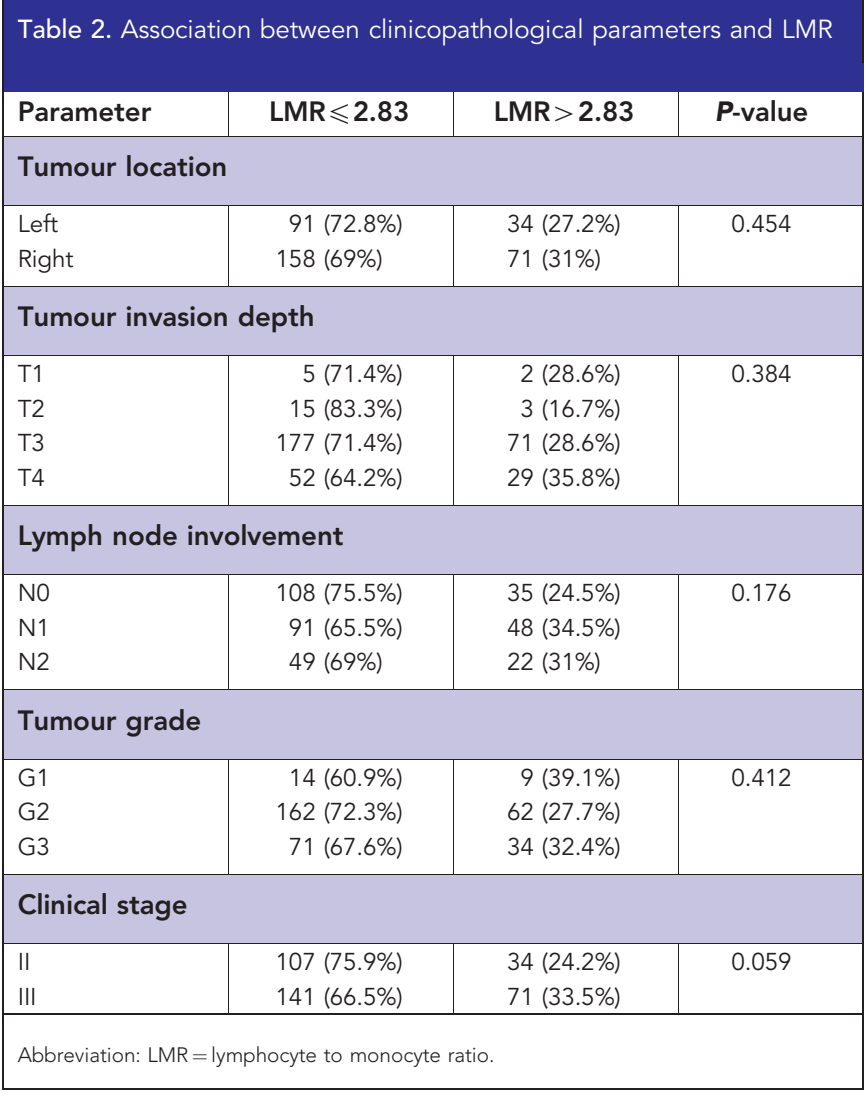

was shown to be associated with poorer prognosis in different tumour entities including colorectal cancer (Mroczko et al, 2007). Evani et al found that monocytes have a role in tumour metastasis in breast cancer by mediating the adhesion of tumour cells to the endothelium (Evani et al, 2013). Similar results were found by Condeelis and Pollard (2006), implicating macrophages for tumour cell migration and invasion. Moreover, macrophages are capable of producing SPARC/osteonectin, which is essential in forming metastasis (Sangaletti et al, 2008). This evidence suggests a protumorous potential of monocytes due to formation of different macrophage phenotypes that promote the malignant process (Swann et al, 2008). The circulating level of monocytes may reflect an increased production of tissue macrophages as a surrogate marker for high tumour burden. A recent meta-analysis summarises the impact of immune cells including lymphocytes and macrophages on clinical outcome from more than 120 published articles. Beyond colorectal cancer, a strong T-cell infiltration associated with good clinical outcome has been reported in many different tumours. High densities of T cells $(\mathrm{CD} 3+)$, of cytotoxic $\mathrm{T}$ cells $(\mathrm{CD} 8+)$ and of memory $\mathrm{T}$ cells $(\mathrm{CD} 45 \mathrm{RO}+)$ were clearly associated with a longer disease-free survival (after surgical resection of the primary tumour) and/or OS. The prognostic impact of other immune cells such as macrophages may differ depending on the type of cancer and on the cancer stage (Mlecnik et al, 2011; Fridman et al, 2012; Galon et al, 2012; Bindea et al, 2013; Galon et al, 2013).

In our study cohort, an increased LMR was significantly associated with increased TTR and OS. This is in line with studies by Li et al (2012) and Batty et al showing similar results in diffuse large B-cell lymphoma (Batty et al, 2013). In classic Hodgkin Lymphoma and nodular lymphocyte-predominant Hodgkin disease, Porrata et al (2012a, b) also identified the LMR as a prognostic marker. When we compared the effect of the LMR in patients with stage II and III separately, we found a significant association only 

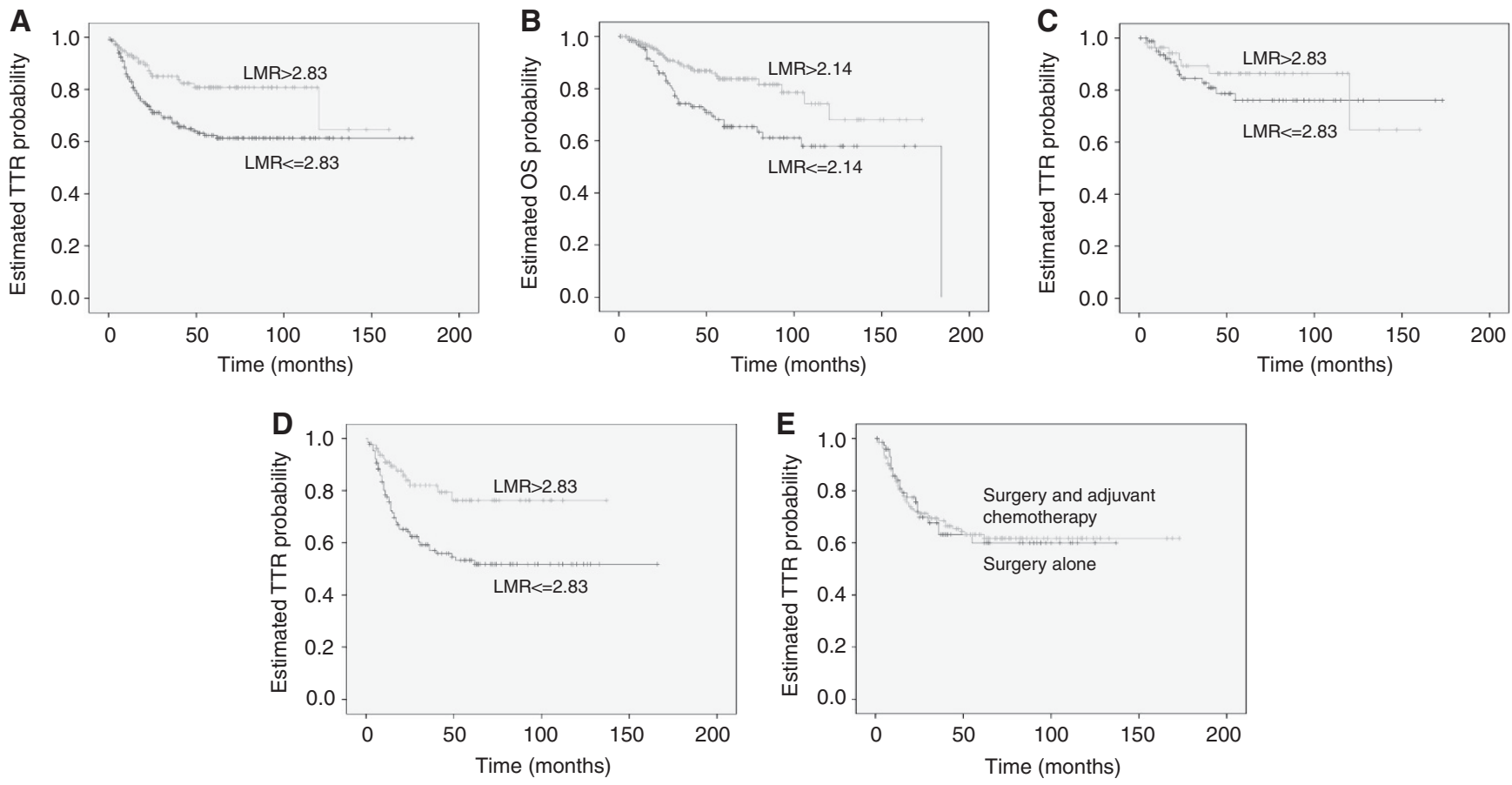

Figure 2. (A) Preoperative LMR and TTR in all colon cancer patients. (B) Preoperative LMR and OS in all colon cancer patients. (C) Association between LMR and TTR in stage II colon cancer patients. (D) Association between LMR and TTR in stage III colon cancer patients. (E) Association between adjuvant chemotherapy or surgery alone and TTR in 'high-risk' colon cancer patients based on LMR $\leqslant 2.83$.

in stage III but not in stage II. Furthermore, when the subgroup of patients with 'high-risk' LMR $\leqslant 2.83$ was analysed, no benefit of adjuvant 5-FU-based chemotherapy could be found.

The strength of this study is the large sample size and the long follow-up period. Moreover, the LMR provides an easy and general available and low price biomarker. However, because of the retrospective design of the study, we cannot fully exclude a selection bias in our study cohort. Since the white blood cell count was obtained preoperative for routine clinical practice and analysed in the general routine laboratory of our hospital, we did not perform specific quality control analysis. Furthermore, because of the exploratory nature of this study, we calculated optimised LMR cutoff levels for TTR und OS using ROC analysis. If different cutoff levels for different end points are valuable or if one threshold level can reliably predict different end points needs to be determined in validation studies. Finally, potential confounding factors, such as local or systemic infection, ischaemia, acute coronary syndrome, metabolic syndrome, diabetes mellitus and renal or hepatic dysfunction, that might affect the lymphocyte and monocyte counts have not been assessed.

Our study may support the conclusion that a low LMR is a negative prognostic marker in stage III colon cancer patients, and that high-risk patients based on the LMR do not benefit from adjuvant chemotherapy.

\section{REFERENCES}

Absenger G, Szkandera J, Pichler M, Stotz M, Arminger F, Weissmueller M, Schaberl-Moser R, Samonigg H, Stojakovic T, Gerger A (2013) A derived neutrophil to lymphocyte ratio predicts clinical outcome in stage II and III colon cancer patients. Br J Cancer 109(2): 395-400.

Allavena P, Garlanda C, Borrello MG, Sica A, Mantovani A (2008) Pathways connecting inflammation and cancer. Curr Opin Genet Dev 18(1): 3-10.

Batty N, Ghonimi E, Feng L, Fayad L, Younes A, Rodriguez MA, Romaguera JE, McLaughlin P, Samaniego F, Kwak LW, Hagemeister Jr FB (2013)

The absolute monocyte and lymphocyte prognostic index for patients with diffuse large B-cell lymphoma who receive R-CHOP. Clin Lymphoma Myeloma Leukemia 13(1): 15-18.

Bindea G, Mlecnik B, Tosolini M, Kirilovsky A, Waldner M, Obenauf AC, Angell H, Fredriksen T, Lafontaine L, Berger A, Bruneval P, Fridman WH, Becker C, Pages F, Speicher MR, Trajanoski Z, Galon J (2013) Spatiotemporal dynamics of intratumoral immune cells reveal the immune landscape in human cancer. Immunity 39(4): 782-795.

Bingle L, Brown NJ, Lewis CE (2002) The role of tumour-associated macrophages in tumour progression: implications for new anticancer therapies. J Pathol 196(3): 254-265.

Cho H, Hur HW, Kim SW, Kim SH, Kim JH, Kim YT, Lee K (2009) Pre-treatment neutrophil to lymphocyte ratio is elevated in epithelial ovarian cancer and predicts survival after treatment. Cancer Immunol Immunother 58(1): 15-23.

Condeelis J, Pollard JW (2006) Macrophages: obligate partners for tumor cell migration, invasion, and metastasis. Cell 124(2): 263-266.

Dunn GP, Old LJ, Schreiber RD (2004) The immunobiology of cancer immunosurveillance and immunoediting. Immunity 21(2): 137-148.

Evani SJ, Prabhu RG, Gnanaruban V, Finol EA, Ramasubramanian AK (2013) Monocytes mediate metastatic breast tumor cell adhesion to endothelium under flow. FASEB J 27(8): 3017-3029.

Fidler IJ, Schroit AJ (1988) Recognition and destruction of neoplastic cells by activated macrophages: discrimination of altered self. Biochim Biophys Acta 948(2): 151-173.

Fridman WH, Pages F, Sautes-Fridman C, Galon J (2012) The immune contexture in human tumours: impact on clinical outcome. Nat Rev Cancer 12(4): 298-306.

Galon J, Mlecnik B, Bindea G, Angell HK, Berger A, Lagorce C, Lugli A, Zlobec I, Hartmann A, Bifulco C, Nagtegaal ID, Palmqvist R, Masucci GV, Botti G, Tatangelo F, Delrio P, Maio M, Laghi L, Grizzi F, Asslaber M, D'Arrigo C, Vidal-Vanaclocha F, Zavadova E, Chouchane L, Ohashi PS, Hafezi-Bakhtiari S, Wouters BG, Roehrl M, Nguyen L, Kawakami Y, Hazama S, Okuno K, Ogino S, Gibbs P, Waring P, Sato N, Torigoe T, Itoh K, Patel PS, Shukla SN, Wang Y, Kopetz S, Sinicrope FA, Scripcariu V, Ascierto PA, Marincola FM, Fox BA, Pages F (2013) Towards the introduction of the Immunoscore in the classification of malignant tumors. J Pathol; e-pub ahead of print 3 October 2013; doi:10.1002/path.4287.

Galon J, Pages F, Marincola FM, Angell HK, Thurin M, Lugli A, Zlobec I, Berger A, Bifulco C, Botti G, Tatangelo F, Britten CM, Kreiter S, Chouchane L, Delrio P, Arndt H, Asslaber M, Maio M, Masucci GV, 
Mihm M, Vidal-Vanaclocha F, Allison JP, Gnjatic S, Hakansson L, Huber C, Singh-Jasuja H, Ottensmeier C, Zwierzina H, Laghi L, Grizzi F, Ohashi PS, Shaw PA, Clarke BA, Wouters BG, Kawakami Y, Hazama S, Okuno K, Wang E, O’Donnell-Tormey J, Lagorce C, Pawelec G, Nishimura MI, Hawkins R, Lapointe R, Lundqvist A, Khleif SN, Ogino S, Gibbs P, Waring P, Sato N, Torigoe T, Itoh K, Patel PS, Shukla SN, Palmqvist R, Nagtegaal ID, Wang Y, D’Arrigo C, Kopetz S, Sinicrope FA, Trinchieri G, Gajewski TF, Ascierto PA, Fox BA (2012) Cancer classification using the Immunoscore: a worldwide task force. J Transl Med 10: 205.

Gomez D, Farid S, Malik HZ, Young AL, Toogood GJ, Lodge JP, Prasad KR (2008) Preoperative neutrophil-to-lymphocyte ratio as a prognostic predictor after curative resection for hepatocellular carcinoma. World J Surgery 32(8): 1757-1762.

Heuff G, Oldenburg HS, Boutkan H, Visser JJ, Beelen RH, Van Rooijen N, Dijkstra CD, Meyer S (1993) Enhanced tumour growth in the rat liver after selective elimination of Kupffer cells. Cancer Immunol Immunother 37(2): 125-130.

Hoffmann TK, Dworacki G, Tsukihiro T, Meidenbauer N, Gooding W, Johnson JT, Whiteside TL (2002) Spontaneous apoptosis of circulating T lymphocytes in patients with head and neck cancer and its clinical importance. Clin Cancer Res 8(8): 2553-2562.

Idowu OK, Ding Q, Taktak AF, Chandrasekar CR, Yin Q (2012) Clinical implication of pretreatment neutrophil to lymphocyte ratio in soft tissue sarcoma. Biomarkers 17(6): 539-544.

Kaneko M, Nozawa H, Sasaki K, Hongo K, Hiyoshi M, Tada N, Murono K, Nirei T, Kawai K, Sunami E, Tsuno NH, Kitayama J (2012) Elevated neutrophil to lymphocyte ratio predicts poor prognosis in advanced colorectal cancer patients receiving oxaliplatin-based chemotherapy. Oncology 82(5): 261-268.

Kwon HC, Kim SH, Oh SY, Lee S, Lee JH, Choi HJ, Park KJ, Roh MS, Kim SG, Kim HJ, Lee JH (2012) Clinical significance of preoperative neutrophillymphocyte versus platelet-lymphocyte ratio in patients with operable colorectal cancer. Biomarkers 17(3): 216-222.

Li ZM, Huang JJ, Xia Y, Sun J, Huang Y, Wang Y, Zhu YJ, Li YJ, Zhao W, Wei WX, Lin TY, Huang HQ, Jiang WQ (2012) Blood lymphocyte-tomonocyte ratio identifies high-risk patients in diffuse large B-cell lymphoma treated with R-CHOP. PloS One 7(7): e41658.

Mantovani A, Allavena P, Sica A, Balkwill F (2008) Cancer-related inflammation. Nature 454(7203): 436-444.

Mlecnik B, Tosolini M, Kirilovsky A, Berger A, Bindea G, Meatchi T, Bruneval P, Trajanoski Z, Fridman WH, Pages F, Galon J (2011) Histopathologic-based prognostic factors of colorectal cancers are associated with the state of the local immune reaction. J Clin Oncol 29(6): 610-618.

Mroczko B, Groblewska M, Wereszczynska-Siemiatkowska U, Okulczyk B, Kedra B, Laszewicz W, Dabrowski A, Szmitkowski M (2007) Serum macrophage-colony stimulating factor levels in colorectal cancer patients correlate with lymph node metastasis and poor prognosis. Clin Chim Acta 380(1-2): 208-212.

Mytar B, Baj-Krzyworzeka M, Majka M, Stankiewicz D, Zembala M (2008) Human monocytes both enhance and inhibit the growth of human pancreatic cancer in SCID mice. Anticancer Res 28(1A): 187-192.

O'Connell JB, Maggard MA, Ko CY (2004) Colon cancer survival rates with the new American Joint Committee on Cancer sixth edition staging. J Natl Cancer Inst 96(19): 1420-1425.

Pollard JW (2004) Tumour-educated macrophages promote tumour progression and metastasis. Nat Rev Cancer 4(1): 71-78.

Pollard JW (2009) Trophic macrophages in development and disease. Nat Rev Immunol 9(4): 259-270.

Porrata LF, Ristow K, Colgan JP, Habermann TM, Witzig TE, Inwards DJ, Ansell SM, Micallef IN, Johnston PB, Nowakowski GS, Thompson C,
Markovic SN (2012a) Peripheral blood lymphocyte/monocyte ratio at diagnosis and survival in classical Hodgkin's lymphoma. Haematologica 97(2): 262-269.

Porrata LF, Ristow K, Habermann TM, Witzig TE, Colgan JP, Inwards DJ, Ansell SM, Micallef IN, Johnston PB, Nowakowski GS, Thompson C, Markovic SN (2012b) Peripheral blood lymphocyte/monocyte ratio at diagnosis and survival in nodular lymphocyte-predominant Hodgkin lymphoma. Br J Haematol 157(3): 321-330.

Rabinowich H, Cohen R, Bruderman I, Steiner Z, Klajman A (1987) Functional analysis of mononuclear cells infiltrating into tumors: lysis of autologous human tumor cells by cultured infiltrating lymphocytes. Cancer Res 47(1): 173-177.

Raungkaewmanee S, Tangjitgamol S, Manusirivithaya S, Srijaipracharoen S, Thavaramara T (2012) Platelet to lymphocyte ratio as a prognostic factor for epithelial ovarian cancer. J Gynecol Oncol 23(4): 265-273.

Rosenberg SA (2001) Progress in human tumour immunology and immunotherapy. Nature 411(6835): 380-384.

Roth AD, Tejpar S, Delorenzi M, Yan P, Fiocca R, Klingbiel D, Dietrich D, Biesmans B, Bodoky G, Barone C, Aranda E, Nordlinger B, Cisar L, Labianca R, Cunningham D, Van Cutsem E, Bosman F (2010) Prognostic role of KRAS and BRAF in stage II and III resected colon cancer: results of the translational study on the PETACC-3, EORTC 40993, SAKK 60-00 trial. J Clin Oncol 28(3): 466-474.

Salazar R, Roepman P, Capella G, Moreno V, Simon I, Dreezen C, Lopez-Doriga A, Santos C, Marijnen C, Westerga J, Bruin S, Kerr D, Kuppen P, van de Velde C, Morreau H, Van Velthuysen L, Glas AM, Van't Veer LJ, Tollenaar R (2011) Gene expression signature to improve prognosis prediction of stage II and III colorectal cancer. J Clin Oncol 29(1): 17-24.

Sangaletti S, Di Carlo E, Gariboldi S, Miotti S, Cappetti B, Parenza M, Rumio C, Brekken RA, Chiodoni C, Colombo MP (2008) Macrophage-derived SPARC bridges tumor cell-extracellular matrix interactions toward metastasis. Cancer Res 68(21): 9050-9059.

Schmoll HJ, Van Cutsem E, Stein A, Valentini V, Glimelius B, Haustermans K, Nordlinger B, van de Velde CJ, Balmana J, Regula J, Nagtegaal ID, Beets-Tan RG, Arnold D, Ciardiello F, Hoff P, Kerr D, Kohne CH, Labianca R, Price T, Scheithauer W, Sobrero A, Tabernero J, Aderka D, Barroso S, Bodoky G, Douillard JY, El Ghazaly H, Gallardo J, Garin A, Glynne-Jones R, Jordan K, Meshcheryakov A, Papamichail D, Pfeiffer P, Souglakos I, Turhal S, Cervantes A (2012) ESMO Consensus Guidelines for management of patients with colon and rectal cancer. a personalized approach to clinical decision making. Annals Oncol 23(10): 2479-2516.

Siegel R, Naishadham D, Jemal A (2013) Cancer statistics, 2013. CA Cancer $J$ Clin 63(1): 11-30.

Swann JB, Vesely MD, Silva A, Sharkey J, Akira S, Schreiber RD, Smyth MJ (2008) Demonstration of inflammation-induced cancer and cancer immunoediting during primary tumorigenesis. Proc Natl Acad Sci USA 105(2): 652-656.

Zikos TA, Donnenberg AD, Landreneau RJ, Luketich JD, Donnenberg VS (2011) Lung T-cell subset composition at the time of surgical resection is a prognostic indicator in non-small cell lung cancer. Cancer Immunol Immunother 60(6): 819-827.

This work is published under the standard license to publish agreement. After 12 months the work will become freely available and the license terms will switch to a Creative Commons AttributionNonCommercial-Share Alike 3.0 Unported License. 